\title{
Improving Student Success Through Hybrid Mode of Delivery in Nonscience Major Biology Classes
}

\author{
Farahnaz Movahe dzade h
}

Department of Biological Sciences, Harold Washington College, 30 E. Lake Street,Chicago IL 60601, USA

\begin{abstract}
Three models of course delivery are being used in higher education in North America: onsite, online, and hybrid learning. This study examines the hypothesis that non-science majors perform at least as well when taking introductory biology in a hybrid delivery format as they do in a traditional onsite format. At Harold Washington College, a hybrid biology course for non-science majors was offered for the first time in 2010 and the effectiveness of the course for achieving its intended outcomes was evaluated. Multiple assessment strategies were used to measure students' success in terms of ach ieving a high rate of student performance, student satisfaction, and student retention.
\end{abstract}

Keywords Student Success, Hybrid, Nonscience Major, Bio logy

\section{Introduction}

In the last few years, it has become increasingly apparent to many educators and academic leaders that the traditional approaches to teaching and learning are no longer successful at helping most students achieve their educational objectives. The need to enhance learning by integrating models, imaging, computer-assisted learning, problem-based learning, and so on, has become an urgent necessity to successfully educate the twenty-first century learners to adapt to both how they learn and to global changes[1,2]. Blended learning, which is based on a mixture of collaborative learning, problem-based learning (PBL), and independent learning, has become an increasingly popular form of web- and e-learning. It is particularly suitable to the process of transitioning towards e-learning from traditional forms of teaching and learning [3]. Blended (hybrid) learning is defined as a coherent design approach that integrates the strengths of face-to-face and online learning to address worthwhile educational goals [4]. There is extensive evidence in the literature of the effectiveness of blended learning in comparison with both online and onsite instruction[5,6], especially in achieving more positive attitudes toward learning and achievement of course learning objectives[7].It has been suggested that Web-based learning combined with traditional face-to-face learning may serve as a good way to get students more motivated to engage in their own learning process and, in turnsuccess fully co mplete their schoolwork and assignments

* Corresponding author:

fmovahedzadeh@ccc.edu (FarahnazMovahed zadeh)

Published online at http://journal.sapub.org/edu

Copyright (C) 2012 Scientific \& Academic Publishing. All Rights Reserved in both introductory[8] as well as higher- level science courses at the college level[1].

While both onsite and online learning can accomplish course and program objectives, in a blended system these modes of learning are combined inorder to enhance the teaching and learningexperience for both faculty and students. Blended learning incorporates the use of asynchronous teaching (facilitated by computer-based technologies) into traditional onsite teaching in order to maximize both teaching and learning opportunities [9].

While the number of students who prefer the blended learning format is rapidly increasing, the number of blended courses offered by institutions is not matching the students' increasing demand for these courses[10]. A number of non-science courses at Harold Washington College (HWC) in Chicago have already been taught successfully using the hybrid delivery format. However, no science course had been taught using the hybrid delivery format until 2010 , whenBiology 114, an introductory biology course for non-science majors, was delivered using a hybrid approach. This paper describes the results of thatBiology 114 (Bio 114) course.The hypothesis was that non-science majors perform at least as well when taking introductory biology in a hybrid delivery format as they do in a traditional onsite format. Students' overall performance and satisfaction with the course, as well as retention rates, were measured in both the hybrid and traditional sections of Bio 114 in order to determine the success and effectiveness of the hybrid format.

\section{Methodology}

\subsection{Course Description}

Biol14 is one of the most popular introductory science courses offered at HWC. The course emphasizes scientific 
inquiry through selected concepts of biology, such as organization, function, heredity, evolution, and ecology, etc. The course als o discuss es biological is sues with personal and sociological implications, enabling students to make informed decisions. The course is offered every semester and is four credit hours. In a face-to-face format, students meet twice a week; one class meeting for lecture and one class for laboratory.

\subsection{Course Re-design and Implementation}

After several years of research and collecting data, Bio 114 was designed as a hybrid course.Concepts and topics taught in the course wereseparated into two categories:those thatneeded to be taught face-to-face in the classroom and those thatcould be learned online.

Upon completing the design of the course, the Blackboard electronic course shell, and its associated materials, the development of the course was under way, which required finding the right resources including reading materials, animations, activities, labs, and inquiry based research projects, etc. Finally, a customized textbook and weekly interactive lectures based on the topics selected were created. Upon the completion of all these processes, which took one year to complete, Bio 114 was offered in a hybrid format during the Spring 2010 semester at HWC. The course met once a week with $60 \%$ of the class ons ite and $40 \%$ online. In this plan, the following components of the course were online: reading the lecture materials and lab materials, conducting virtual labs as practice and preparation for actual labs on campus, taking quizzes, and research group projects. The onsite class meetings included lectures, discussions, exams, and laboratories.

\subsection{Ass essing Student Success}

Student success is measured in terms of achieving high rates of student performance, satisfaction, and retention[11]. Assessing the success of the hybrid Bio 114 course was accomplished by:

- Teaching the same course content in both hybrid and traditional formats.

- Conducting concept-based pre- and post-tests.

- Surveying the students in both the hybrid and the traditional course of Biology 114 at the end of the semester.

- The overall grades of students in both the hybrid and the traditional classes.

- Students' Class Evaluation administrated by the college in both the hybrid and the traditional sections.

To gather data to measure students' performance in and satisfaction with the hybrid course delivery, questionnaires were used to solicit responses from students who completed Bio 114 in a hybrid or traditional delivery format. The questionnaire was prepared after broad consultation with biology instructors, science educators, scientists, and students.

A total of 29 questions were used in this student survey (this questionnaire can be obtained upon request). The questions are grouped into four distinguishable groups according to the theme of each question set: (a) Students' Readiness/Awareness of Hybrid courses; (b) Students' Preferred Learning Style; (c) Students' Satisfaction with Course/Instruction; and (d) Personal Data.

The questionnaire was distributed to students at the end of the semester of both Bio 114 classes. The findings from the student survey were compared to the perspectives from the scientific literature.

To evaluate students' satisfaction with the course and instruction, responses were obtained from 25 students in the hybrid class and from 34 students in the traditional Bio114 class. Students' academic performance was measured by comparing the overall grades for both hybrid and traditional sections of Bio 114. The overall grades covered the quizzes and exams, ho mework as signments, labs, class activities, etc. In addition, students took a pre- and post-test that was given to students in both classes on the first and last days of the course. Table 1 summarizes the actions and explanation of the data-gathering mechanis ms used in the study.

Table 1. Data Used To Evaluate the Traditional and theHybrid learning Models of Biology 114

\begin{tabular}{|c|c|c|}
\hline & $\begin{array}{l}\text { Data-Gathering } \\
\text { Mechanism }\end{array}$ & Actions and Explanation \\
\hline 1 & Pre- and post-test & $\begin{array}{l}\text { To measure students' academic } \\
\text { performance and mastery of learning. At } \\
\text { the beginning of the course (first day) a } \\
\text { pre-test was given to students in both } \\
\text { classes. The same test was given to both } \\
\text { classes on the last day of the course. }\end{array}$ \\
\hline 2 & Overall grades & $\begin{array}{l}\text { The overall grades for both classes were } \\
\text { compared. }\end{array}$ \\
\hline 3 & $\begin{array}{l}\text { Number of students } \\
\text { who successfully } \\
\text { completed the } \\
\text { courses. }\end{array}$ & $\begin{array}{l}\text { Retention rates between the two classes } \\
\text { were measured based on the number of } \\
\text { students who completed the course. }\end{array}$ \\
\hline 4 & $\begin{array}{l}\text { Survey: Students' } \\
\text { performance and } \\
\text { satisfaction }\end{array}$ & $\begin{array}{l}\text { To evaluate students' performance and } \\
\text { satisfaction, a survey was distributed at the } \\
\text { end of each class which contained } 29 \\
\text { questions. }\end{array}$ \\
\hline 5 & $\begin{array}{l}\text { Students' Class } \\
\text { Evaluation }\end{array}$ & $\begin{array}{l}\text { The related items to students' sat isfaction } \\
\text { with the course, instruction, instructor, and } \\
\text { students' own mast ery of learning in the } \\
\text { Student Class Evaluation were selected, } \\
\text { analysed, and used. }\end{array}$ \\
\hline
\end{tabular}

\section{Results}

\subsection{Analysis of the Results from the Students' Perfor mance and Satisfaction Survey}

Category III questions from the Satisfaction Survey focus on the students' Satisfaction with the Course and Instruction (SCI) in both the hybrid and the traditional versions of Bio114. The analys is of this group of questions shows that the majority of students in both Biol14 sections were satis fied with the course. In addition, as seen in Table 2, all students in the hybrid section and a majority of students in the traditional section were willing and ready to recommend the course to other students. 
Table 2. Cat egory III Questions of the Satisfaction Survey: Results of Questions 9 and 10

\begin{tabular}{|c|c|c|c|c|c|}
\hline \multirow{2}{*}{$\begin{array}{l}\text { Q. } \\
\text { No. }\end{array}$} & \multirow[t]{2}{*}{ Question } & \multicolumn{2}{|c|}{ Hybrid Bio 114} & \multicolumn{2}{|c|}{$\begin{array}{c}\text { Traditional Bio } \\
114 \\
\end{array}$} \\
\hline & & Agree & Disagree & Agree & Disagree \\
\hline \multirow[b]{2}{*}{9} & \multirow[b]{2}{*}{$\begin{array}{l}\text { In the Biology-114 } \\
\text { class that It took in } \\
\text { Spring } 2010 \text { at } \\
\text { Harold } \\
\text { Washington } \\
\text { College, I was } \\
\text { taught well and } \\
\text { challenged to do } \\
\text { my best in my } \\
\text { subjects in the } \\
\text { course. }\end{array}$} & $92 \%$ & $8 \%$ & $93.8 \%$ & $6.3 \%$ \\
\hline & & 23 & 2 & 15 & 1 \\
\hline & \multirow[b]{2}{*}{$\begin{array}{l}\text { In the Biology-114 } \\
\text { class that It ook in } \\
\text { Spring } 2010 \text { at } \\
\text { HWC, I was helped } \\
\text { and encouraged to } \\
\text { study and research } \\
\text { topics } \\
\text { independently. }\end{array}$} & $91.3 \%$ & $8.7 \%$ & $83.3 \%$ & $16.7 \%$ \\
\hline 10 & & 21 & 2 & 15 & 3 \\
\hline
\end{tabular}

Furthermore, as shown in Table 3, $80 \%$ of students in the hybrid section and $50 \%$ of students in the traditional course believed that the quality of instruction was higher or much higher than other traditional classes they had taken. While $3.6 \%$ of students fro $m$ the traditional section rated the quality of instruction lower in comparison to other courses, no students from the hybrid section did.
Table 3. Category III Questions of the Satisfaction SurveyResults of Question 11

\begin{tabular}{|c|c|c|}
\hline \multicolumn{3}{|c|}{$\begin{array}{r}\text { 11. Rate the overall quality of interaction with the instructor } \\
\text { compared to other classes you have taken: }\end{array}$} \\
\hline & Hybrid Bio-1 14 & Traditional Bio-1 14 \\
\hline \multirow{2}{*}{ Much Higher } & $36 \%$ & $14.3 \%$ \\
\cline { 2 - 3 } & 9 & 4 \\
\hline \multirow{2}{*}{ Higher } & $44 \%$ & $35.7 \%$ \\
\cline { 2 - 3 } & 11 & 10 \\
\hline \multirow{2}{*}{ About the Same } & $20 \%$ & $42.9 \%$ \\
\cline { 2 - 3 } & 5 & 12 \\
\hline \multirow{2}{*}{ Lower } & $0 \%$ & $3.6 \%$ \\
\cline { 2 - 3 } & 0 & 1 \\
\hline \multirow{2}{*}{ Much Lower } & $0 \%$ & $3.6 \%$ \\
\cline { 2 - 3 } & 0 & 1 \\
\hline
\end{tabular}

Finally, as shown in Table 4, a large majority of the students in both sections $(88 \%$ in hybrid and $80.7 \%$ in traditional) were satisfied with their own ability to demons trate mastery of course objectives. In addition, mo re students in the traditional section (19.4\%) than in the hybrid section (12\%) reported being less satisfied with their own ability to demonstrate mastery of course objectives. However, the students' highest satisfaction with the course was measured by their willingness to recommend the course to other students at HWC. As shown in Table 5, in the hybrid section the rate was $100 \%$ and in the traditional section the rate was $90.4 \%$.

Table 4. Cat egory III Questions of the Satisfact ion Survey:Results of Questions 12 - 20

\begin{tabular}{|c|c|c|c|c|c|c|c|}
\hline \multirow[b]{2}{*}{ Q. No. } & \multirow[b]{2}{*}{ Question } & \multicolumn{3}{|c|}{ Hybrid Bio-1 14} & \multicolumn{3}{|c|}{ Traditional Bio-1 14} \\
\hline & & Excellent & Good & Not Good & Excellent & Good & Not Good \\
\hline \multirow{2}{*}{12} & \multirow{2}{*}{$\begin{array}{l}\text { How would you rate the } \\
\text { performance of your } \\
\text { instructor in this Hybrid } \\
\text { course in terms of } \\
\text { respect for students? }\end{array}$} & $88 \%$ & $12 \%$ & $0 \%$ & $42.9 \%$ & $57.1 \%$ & $0 \%$ \\
\hline & & 22 & 3 & 0 & 9 & 12 & 0 \\
\hline \multirow{2}{*}{13} & \multirow{2}{*}{$\begin{array}{l}\text { How would you rate the } \\
\text { performance of your } \\
\text { instructor in this Hybrid } \\
\text { course (degree of } \\
\text { preparation)? }\end{array}$} & $84 \%$ & $16 \%$ & $0 \%$ & $52.6 \%$ & $42.1 \%$ & $5.3 \%$ \\
\hline & & 21 & 4 & 0 & 10 & 8 & 1 \\
\hline \multirow{2}{*}{14} & \multirow{2}{*}{$\begin{array}{l}\text { Presentation skills } \\
\text { (organized, clear, } \\
\text { summarizes concepts; } \\
\text { refers to prior and future } \\
\text { topics). }\end{array}$} & $84 \%$ & $16 \%$ & $0 \%$ & $43.3 \%$ & $56.7 \%$ & $0 \%$ \\
\hline & & 21 & 4 & 0 & 13 & 17 & 0 \\
\hline \multirow{2}{*}{15} & \multirow{2}{*}{$\begin{array}{l}\text { Student interaction } \\
\text { (probes for } \\
\text { understanding). }\end{array}$} & $44 \%$ & $56 \%$ & $0 \%$ & $33.3 \%$ & $63.6 \%$ & $3 \%$ \\
\hline & & 11 & 14 & 0 & 11 & 21 & 1 \\
\hline \multirow[b]{2}{*}{16} & \multirow{2}{*}{$\begin{array}{c}\text { Feedback/ } \\
\text { communication } \\
\text { (available by email/ } \\
\text { office hours). }\end{array}$} & $84 \%$ & $16 \%$ & $0 \%$ & $53.1 \%$ & $43.8 \%$ & $3.1 \%$ \\
\hline & & 21 & 4 & 0 & 17 & 14 & 1 \\
\hline \multirow{2}{*}{20} & \multirow{2}{*}{$\begin{array}{c}\text { How would you rate } \\
\text { your ability to } \\
\text { demonstrate mastery of } \\
\text { the course objectives? }\end{array}$} & $20 \%$ & $68 \%$ & $12 \%$ & $19.4 \%$ & $61.3 \%$ & $19.4 \%$ \\
\hline & & 5 & 17 & 3 & 6 & 19 & 6 \\
\hline
\end{tabular}


Table 5. Cat egory III Questions of the Satisfaction Survey: Results of Question 21

\begin{tabular}{|c|c|c|c|c|c|c|c|}
\hline \multirow{2}{*}{ No. } & & \multicolumn{3}{|c|}{ Hybrid Bio-1 14 } & \multicolumn{3}{|c|}{ Traditional Bio-1 14 } \\
\cline { 3 - 9 } & Question & $\begin{array}{c}\text { Not at } \\
\text { All }\end{array}$ & Suggest & $\begin{array}{c}\text { Strongly } \\
\text { Suggest }\end{array}$ & Not at All & Suggest & $\begin{array}{c}\text { Strongly } \\
\text { Suggest }\end{array}$ \\
\hline \multirow{2}{*}{21} & $\begin{array}{c}\text { Would you } \\
\text { recommend this } \\
\text { course to others? }\end{array}$ & $0 \%$ & $62.5 \%$ & $37.5 \%$ & $9.7 \%$ & $58.1 \%$ & $32.3 \%$ \\
\cline { 3 - 9 } & & 0 & 15 & 9 & 3 & 18 & 10 \\
\hline
\end{tabular}

In summary, the majority of students in both hybrid and traditional sections of Biol14 indicated that they were satisfied with the quality of instruction and how they were taught, and agreed that they had been challenged to do their best and had received the required respect, encouragement, and opportunities to study (Table 2). They were also satis fied with the quality of the instructor's performance in teaching the subject matter, as well as the instructor's presentation skills, including organization, clearness, summarizing concepts, and referring to prior topics (Table 4). Students were satisfied with their own ability to demonstrate mastery of course objectives after Bio 114. Their ultimate satisfaction with the course, the instruction, and the instructor was measured by their willingness to recommend the course to others: $100 \%$ of students in the hybrid section and $90.4 \%$ of students in the traditional section would recommend this course to others (Table 5).

\subsection{Analysis of the Results from the Students' Acade mic Performance}

Students' academic performance was measured based on comparing the overall grades for both hybrid and traditional sections of Bio114 and on the pre- and post-tests that were given to students in both classes on the first and last days of the course.

\subsection{Student Overall Grades}

Twenty-five out of 28 students in the hybrid section, and 34 out of 36 students in the traditional section completed and received grades for the course. Table 6 shows a comparison of the overall student grades in both sections. The mean of the final grades in the traditional class was $80.14 \%$, ranging from $46.11 \%$ to $97.20 \%$. The mean of final grades in the hybrid course was $83.77 \%$, ranging from $60.13 \%$ to $97.32 \%$. The highest grade was obtained by a student from the hybrid class. The standard deviation was calculated as 11.5 for the traditional class and 8.8 for the hybrid class, as shown in Table 6 .

Table 6. Comparison of the Mean and the Standard Deviation of the Overall Student Grades in Both Hybrid and Traditional Sections of Bio-114

\begin{tabular}{|c|c|c|}
\hline Delivery Style & Mean & Standard Deviation \\
\hline Traditional cou rse & $\mathbf{8 0 . 1 4 \%}$ & $\mathbf{1 1 . 5}$ \\
\hline Hybrid course & $\mathbf{8 3 . 7 7 \%}$ & $\mathbf{8 . 8}$ \\
\hline
\end{tabular}

\subsection{Acade mic Achievement us. Passing the Course}

Based on college policy and regulations, a student must obtain an A, B, C, or D grade in order to pass the course.
However, for the purposes of this study, obtaining a B or better is considered academic achievement beyond just passing the course. As seen in Table 7, the number of students who earned a B or better for the two sections of the course was as follows: 23 of the 34 students $(68 \%)$ in the traditional course, and 20 of the 25 students $(80 \%)$ in the hybrid course.

Table 7. Students' academic achievement as measured by going beyond just passing the course

\begin{tabular}{|c|c|c|c|c|}
\hline \multirow{2}{*}{ Grade } & \multicolumn{2}{|c|}{ Hybrid $(\mathrm{N}=25)$} & \multicolumn{2}{|c|}{ Traditional $(\mathrm{N}=34)$} \\
\hline & $\mathrm{N}$ & $\%$ & $\mathrm{~N}$ & $\%$ \\
\hline B or Better & 20 & $80 \%$ & 23 & $67.6 \%$ \\
\hline $\mathrm{C}$ & 4 & $16 \%$ & 8 & $23.5 \%$ \\
\hline $\bar{D}$ & 1 & $4 \%$ & 2 & $5.9 \%$ \\
\hline $\mathrm{F}$ & 0 & $0 \%$ & 1 & $2.9 \%$ \\
\hline Total & 25 & $100 \%$ & 34 & $100 \%$ \\
\hline
\end{tabular}

Based on analysis of the data in Table 7, students in the hybrid section of Biol14 achieved better academic performance than students in the traditional section of Bio114.

\subsection{Pre- and Post-Test}

Students' academic performance was also measured based on a pre-and post-test that was given to students in both classes on the first and last day of the course. A set of 50 questions which covered the main concepts of biology was prepared, discussed with three biology instructors for feedback, modified, and then administered at the beginning and end of the hybrid and the traditional sections of Bio 114. Table 8 shows the comparative results of the pre- and post-test.

Table 8. Comparative results of the pre- and post-test in both the hybrid and traditional sections of Biology 114

\begin{tabular}{|c|c|c|}
\hline & Pre-test & Post-test \\
\hline Traditional course & $39.2 \%$ & $54.2 \%$ \\
\hline Hybrid course & $43 \%$ & $57.6 \%$ \\
\hline
\end{tabular}

While this class is an introductory biology course for non-science majors, there were six students in the traditional class that were science majors. These six students always obtained better grades and were more attentive; however, none of the students in the hybrid class were science majors. This is very significant because, although the improvement between the two classes seems to be comparable, when the score of the post-test in the traditional section of the course is calculated without the scores of those six science majors, the improvement value went down from $54.2 \%$ to $51.6 \%$. This 
means that the students in the hybrid section of Bio 114 made greater improvement in comparison to the students in the traditional section of the same course.

\subsection{Analysis of Student Retention Rates}

Students' retention was measured based on the number of students who withdrew from the two sections of Bio114 before completing the course in the Spring 2010 semester. The analysis shows that by the end of Spring 2010, the traditional Bio114 course had two registered withdrawals. This result qualified the traditional course for a $94.4 \%$ completion rate. During the same semester, the hybrid Bio1 14 had three registered withdrawals. This qualified the hybrid course for an $89.3 \%$ co mp letion rate. However, we do not have any information to show the real reasons behind students' withdrawal from these two sections.

Table 9 shows while there were more female students in the traditional section $(60.6 \%)$ than the hybrid section $(58.3 \%)$; in both sections there were more female than male students of those who participated in this study. Although the majority of the students in both sections were between 21-29 years of age, there were more students 20 years of age or less in the traditional class, while there were more students between 30-39 years of age in the hybrid class. While in the hybrid section all the students were non-science majors, the majority of them (84\%) were full-time students. In addition, while the majority of them $(80 \%)$ have no college degree, $8 \%$ of students have Associates degrees and another $8 \%$ have Bachelor's/Master's degrees.

Both the hybrid and the traditional sections of Bio 114 were diverse in terms of race and ethnicity. However, as seen in Table 9, the hybrid section was more diverse.

Over half of the participants in both sections considered themselves commuters, because they live more than 5 miles away from the college campus (56\% in the hybrid section and $61.8 \%$ in the traditional section). Furthermore, the majority of students (84\%) in the hybrid section were working while going to school, and only $16 \%$ were unemployed, whereas in the traditional section $61.8 \%$ were working and $38.2 \%$ were unemployed.

\subsection{Analysis of Results from the Student Class Evaluation Administered by the College}

The Student Class Evaluation contains twelve questions and is administered by the college in the absence of the instructor before the end of the semester. Only the items that were relevant to students' satisfaction with the course and instruction in the hybrid Bio 114 section were selected, analyzed, and used in this study. To validate the conclusion drawn from the students' responses to each of the selected questions, I gave the results to two colleagues from different institutions to look at the summaries and the conclusion of each selected question. The Student Class Evaluation complemented the overall results of the two surveys that were designed and conducted for this study.
Table 9. Summary of the Student's Personal Data Portfolio (Questions 22-29 in the Survey)

\begin{tabular}{|c|c|c|c|c|}
\hline No. & Item & Category & $\begin{array}{l}\text { Hybrid } \\
\text { Course } \\
\end{array}$ & $\begin{array}{c}\text { Traditional } \\
\text { Course }\end{array}$ \\
\hline \multirow{2}{*}{22} & \multirow{2}{*}{ Gender } & Female & $58.3 \%$ & $60.6 \%$ \\
\hline & & Male & $41.7 \%$ & $39.4 \%$ \\
\hline \multirow{4}{*}{23} & \multirow{4}{*}{ Age } & 20 or below & $16.7 \%$ & $25 \%$ \\
\hline & & $21-29$ & $66 \%$ & $65.6 \%$ \\
\hline & & $30-39$ & $16 \%$ & $9.4 \%$ \\
\hline & & $40-49$ & $0 \%$ & $0 \%$ \\
\hline \multirow{8}{*}{24} & \multirow{8}{*}{ Race/ethnicity } & $\begin{array}{l}\text { Asian American/Paci fic } \\
\text { Islander }\end{array}$ & $12.5 \%$ & $2.9 \%$ \\
\hline & & A frican American/Black & $37.5 \%$ & $29.4 \%$ \\
\hline & & Caucasian/White & $29.2 \%$ & $29.4 \%$ \\
\hline & & $\begin{array}{c}\text { American } \\
\text { Indian/Alaskan Native } \\
\end{array}$ & $0 \%$ & $0 \%$ \\
\hline & & Hispanic/Latino/Chicano & $4.2 \%$ & $23.5 \%$ \\
\hline & & Multi-racial/Multi-ethnic & $4.2 \%$ & $2.9 \%$ \\
\hline & & Arab/Arab American & $4.2 \%$ & $0 \%$ \\
\hline & & Other & $8.3 \%$ & $11.8 \%$ \\
\hline \multirow{5}{*}{25} & \multirow{5}{*}{$\begin{array}{l}\text { Having } \\
\text { Degree }\end{array}$} & Associates & $8.0 \%$ & $6.3 \%$ \\
\hline & & Bachelor/Master & $8.0 \%$ & $9.4 \%$ \\
\hline & & Doctorate of Philosophy & $0.0 \%$ & $0.0 \%$ \\
\hline & & Other & $4.0 \%$ & $12.5 \%$ \\
\hline & & No Degree & $80.0 \%$ & $71.9 \%$ \\
\hline \multirow{2}{*}{26} & \multirow{2}{*}{$\begin{array}{l}\text { Employment } \\
\text { status }\end{array}$} & Not employed & $16.0 \%$ & $38.2 \%$ \\
\hline & & employed & $84.0 \%$ & $61.8 \%$ \\
\hline \multirow{2}{*}{27} & \multirow{2}{*}{$\begin{array}{l}\text { Enrolment } \\
\text { status: }\end{array}$} & Full time & $84.0 \%$ & $52.9 \%$ \\
\hline & & Part time & $16.0 \%$ & $47.1 .0 \%$ \\
\hline \multirow{2}{*}{28} & \multirow{2}{*}{$\begin{array}{l}\text { Resident or } \\
\text { commuter }\end{array}$} & Residence & $44.0 \%$ & $38.2 \%$ \\
\hline & & Commuter & $56.0 \%$ & $61.8 \%$ \\
\hline \multirow{2}{*}{29} & \multirow{2}{*}{ Science major } & Yes & $0.0 \%$ & $17.6 \%$ \\
\hline & & No & $100 \%$ & $82.4 \%$ \\
\hline
\end{tabular}

\section{Discussion and Recommendations}

Student satisfaction and learning are among the key criteria for measuring students' success in a learning environment. This study shows that the majority of students in both the hybrid and traditional sections of Bio114 were satis fied with the quality of instruction and their own ability to demons trate mastery of course objectives and were willing to recommend Bio1 14 to other students.

These findings are supported by the results from:

1) The Student Class Evaluation

2) Students' feedback at the half-way point of the semester.

3) Percentage of students who earned an overall grade of B or better.

While students in both sections of Bio 114 were satisfied with the course, course instruction, course instructor, and their own ability to master the course objectives, students in the hybrid section showed a slightly higher degree of satisfaction than students in the traditional section. Since the hybrid and traditional sections of Bio 114 were taught by the same instructor, it is very hard to know whether or not this can be attributed to different delivery format alone (hybrid and traditional) or the instructor's personal characteristics and intrins ic pedagogical ability to teach and manage courses regardless of their delivery format. There fore, while students' 
satisfaction is important in measuring student success, it cannot be used alone in this study to measure the effectiveness of the hybrid section in comparison to the traditional section. It is however, a testament to the objectivity of the instructor in teaching and managing the two sections, as well as the quality of the two sections, the pedagogical instruction, and the effectiveness of the instructor.

\section{General Recommendations}

The recommendations are organized into three sections: Student Counselling and Advising; Technology, IT, and Infrastructure; and Faculty Support.

\subsection{Student Counseling and Advising}

Forty-eight percent of students who took the hybrid section believed that they were not well-advised by the college's academic advisers before choosing the hybrid course. Therefore, the college's academic advisers might benefit from additional training to help them ensure that students are well informed of the nature of the hybrid courses and the requirements that will help them succeed in these types of courses. In addition, departments that offer hybrid courses and faculty who teach these types of courses need to accurately advertise their courses and make all necessary informat ion available and easily acces sible to students before registration. For example, having computer skills as well as access to a co mputer with Internet access at home, or at so me other location, is one of the keys for success in a hybrid course.

\subsection{Computer and Instructional Technology, IT, and Infr as tructure}

Computer technology, instructional technology, IT, and classroom infrastructure are important components in successfully managing and facilitating a hybrid learning environment. Having a solid understanding of course management systems coupled with reliable Internet access in the classroom and interactive media technologies saves instructors time and energy allowing them to focus on their students and other pedagogical matters in helping students learn and maximize their success.

\subsection{Faculty Support}

Blended instruction does not only offer significant learning advantages for students, but also for faculty and institutions in optimizing access, learning, suitability, elasticity, and resources. However, faculty needs support in teaching hybrid courses. Morote, et al.[12] identified four main categories of needed support that greatly influence faculty decisions to develop and implement hybrid and online courses. These categories include technology, pedagogy, institutional policies, and faculty-centered is sues. Therefore, institutional and departmental commitment in supporting faculty in the areas of technology, pedagogy, and instructional design and course management are needed to motivate faculty to confidently step up and take the initiative to start teaching in a hybrid and/or online learning environment.

\section{Conclusions}

In summary, we can conclude fromthis study's results that hybrid instruction is at least as good as the traditional methodology. In addition, the findings of this study support and reinforce three of the major benefits of hybrid instruction: 1) It provides working students with flexibility, i.e., reduced time in class; 2) It relieves space constraints, by reducing the time spent in class; and 3) It develops high quality digital content, which makes it possible to share best practices across faculty and which thereby helps in the development of a faculty learning community.

\section{ACKNOWLEDGMENTS}

The author would like to thank Mr. William Thompson and Dr Eric Eg li for technicalassistance; Dr. Patrick Mayers, Dr Maris Roze, Dr. Abour Cherif and Ms Erica Solomon for helpful discussion and critically reading the paper and providing comments; and all the students of Harold Washington College who partic ipated actively in this study.

\section{REFERENCES}

[1] Johnson, E. O., Charchanti, A. V., Troupis, T. G. (2012). Modernization of an anatomy class: From conceptualization to implementation. A case for integrated multimodal multidisciplinary teaching. Anatomical Sciences Education, Article first published online: 21 JUN 2012 (DOI:10.1002/ ase.1296)

[2] Quinn, Clark N. (2011). Designing mLearning: Tapping into the Mobile Revolution for Organizational Performance. Pfeiffer, A Wiley Imprint

[3] Hoic-Bozic, N., Mornar, V., \&Boticki, I. (2009). A Blended Learning Approach to Course Design and Implementation. Education, IEEE Transactions, Volume 52, Issue 1, Feb. 2009

[4] Garrison, D. R. and Vaughan, N.D. (2008). Bended Learning In Higher Education: Framework, principles, and Guideline. San Francisco, CA: John Wiley \& Son

[5] Means, B.,Toyama, Y., Murphy, R., Bakia, M., and Jones, K. (2010). Evaluation of Evidence-based Practices in Online Learning: In Meth-analysis and review of Online Learning Studies. U.S. Department of Education: Office of Planning, Evolution, and Policy Development. Washington, DC.http:// www2.ed.gov/rschstat/eval/tech/evidence-based-practices/fi nalreport.pdf

[6] Kolowich, Steve (2009). Sustainable Hybrid: Blended Learning, Preliminary Data Indicate Hybrid Courses Produce Better Outcomes. Inside Higher Ed, Sept. 22, 2009 
(http://www.insidehighered.com/news/2009/09/22/hybrids), $(3 \& 4)$

[7] Carbonaro, M. et al (2008). Integration of e-learning technologies in an interprofessional health science course. Med Teach. 2008 Feb; 30(1):25-33http://www.ncbi.nlm.nih. gov/pubmed/18278648

[8] Movahedzadeh, F. (2011). Improving Students' Attitude toward Science through the Blended, Science Education and Civil Engagement, An International Journal, 3:2

[9] Hrastinski, Stefan (2008).Asynchronous and Synchronous E-Learning. EDUCAUSE Quarterly, 31 (4): 51-55 http://net. educause.edu/ir/library/pdf/EQM0848.pdf

[10] Allen, Elaine, Seaman, Jeff, and Garrett, Richard. (2007). Assessing Consumer Preferences for Continuing,
Professional, and Online Higher Education. United States: Sloan-CTM, March 2007 http://sloanconsortium.org/publicati ons/survey/pdf/Blending_In.pdf

[11] Mayers, P., T. Riccordati, and D. Hohmeier (1995). System-supported teaching and learning to improve student performance, satisfaction, and retention. In Harry V. Roberts (ed.) Academic Initiatives in Total Quality for Higher Education. Milwaukee, Wisconsin: ASQC Quality Press.

[12] Morote, E.S., Wittmann, H. \& Kelly, T. (2007). What really matters for faculty to develop and implement hybrid/blended courses? In R. Carlsen et al. (Eds.), Proceedings of Society for Information Technology \& Teacher Education International Conference 2007 (pp. 1085-1089). Chesapeake, VA: AACE 